\title{
Racial effect on serum creatine-kinase: implications for estimation of heterozygosity risks for females at-risk for Duchenne dystrophy
}

\author{
Maria Rita Passos-Bueno ${ }^{1,3}$, Eliete Rabbi-Bortolini ${ }^{2}$, \\ Eliane Azevêdo ${ }^{1}$ and Mayana Zatz $^{3}$ \\ ${ }^{1}$ Laboratório de Genética Médica, Universidade Federal da Bahia, Salvador, Bahia, ${ }^{2}$ Departamento de \\ Genética, Universidade Federal do Espirito Santo, Vitória, Espirito Santo, and ${ }^{3}$ Centro de Miopatias, \\ Instituto de Biociências, Universidade de São Paulo, São Paulo, São Paulo (Brazil)
}

(Received 12 May 1988; revision received 1 October 1988; accepted 13 October 1988)

Key words: Creatine-kinase; Duchenne muscular dystrophy

\section{Introduction}

Duchenne muscular dystrophy (DMD), a lethal X-linked recessive genetic disorder of childhood, is the most common and severe of the muscular dystrophies. Until no effective treatment is found to cure or arrest the progression of the disease, prevention of new cases through detection of carriers and genetic counseling is fundamental.

About $50 \%$ to $80 \%$ of the heterozygotes for the DMD gene have increased creatine-kinase $(\mathrm{CK})$ and pyruvate-kinase (PK) levels [1-4]. Studies on DNA polymorphisms have greatly improved identification of heterozygotes in informative families. However, techniques of DNA analysis are expensive and time consuming, and the results are not always absolute. Very often, they must be expressed in terms of probabilities, combined with results of serum enzymes determinations. Therefore, serum enzyme determinations will still be important first, as a screening test and second, for calculation of conditional probabilities (combined with DNA marker information through Bayesian methods) in heterozygosity risk estimations for females at risk for DMD [5,6].

Studies on serum CK in normal people from different racial background have shown that the black population has higher serum CK levels than the caucasoids or mongoloids [7-10]. In a recent study, we have compared serum CK and PK in healthy adult females of different black admixture. The preliminary results suggested that while PK did not differ among the different subgroups, CK was significantly higher in the black females than in the caucasoids [11].

Present address to which correspondence should be sent: Maria Rita Passos-Bueno. Centro de Miopatias, Instituto de Biociências, Rua do Matao, 321, Universidade de São Paulo, São Paulo, Brazil, 05508. 
On the other hand, results of serum enzymes in possible and obligate DMD carriers showed that the negroids have also higher serum CK levels than caucasoids [12]. These findings may have important implications in estimation of heterozygosity risks for females at-risk for DMD. In order to evaluate this hypothesis, we have extended this investigation and have determined serum CK and PK in 263 healthy female controls classified as caucasoids, negroids and mongoloids. The results were compared through discriminant analysis with serum enzyme activities from 82 caucasoids and 64 negroids DMD obligate carriers.

\section{Subjects and methods}

Healthy controls: A total of 263 adult healthy females who had no relatives with any neuromuscular disorders were included in the present study. The name, age, menses data, physical activity and racial group was registered for each individual.

According to ethnical origin. skin colour and facial features, the subjects were classified in three racial groups: caucasoids $(\mathrm{C})$, negroids $(\mathrm{N})$ and mongoloids $(\mathrm{M})$. The negroid group was further subdivided in the following 4 subgroups: light mulattoes, medium mulattoes, dark mulattoes and blacks [13].

$D M D$ carriers: Serum CK results from 146 obligate carriers classified as caucasoids $(n=82)$ or negroids $(n=64)$ were considered in the present study. A woman was classified as carrier when: she had a brother or other maternal relative and at least one affected son; two or more affected sons; two or more affected grandsons through different daughters.

Both enzymes were determined in all female controls (40 caucasoids, 50 mongoloids, 173 negroids) and DMD carriers.

Serum PK activity was determined in a Gilford spectrophotometer (model 2400) according to a procedure described elsewhere [14], always in fresh serum since it has been shown that $P K$ activity decreases upon freezing $[2,14]$. The results are given in $\mu \mathrm{mol} / \mathrm{ml}$ per h. Serum CK activity was performed with Sigma kits, in the same aliquots used for PK, with the colorimetric procedure 520-C, according to Hughes [15], as described in Sigma Bulletin [16]. This enzyme reaction is performed at 37 C. Results are given in Sigma units/ml (S.u.). Usually the samples were assayed within $24 \mathrm{~h}$ or at most within $1 \mathrm{wk}$ after collection in aliquots frozen at $-20 \mathrm{C}$, since no loss of enzyme activity has been observed in samples stored up to $2 \mathrm{mth}[15.16]$.

For statistical analysis logarithmic transformation was performed $[\log (C K+1)$, $\log (P K+1)]$ with resulting distributions close to Gaussian ones. For comparing the enzyme activities of females from different racial subgroups, a variance analysis and Student's $t$ test were applied according to each situation. A Tukey $t$ test was used when a significant result was observed in the variance analysis.

The considered level of significance was $5 \%$.

\section{Results}

Results of serum CK and PK determinations (transformed and untransformed data) in normal female controls from the three racial groups are summarized in Table I. 
TABLE I

Serum creatine-kinase (CK), pyruvate-kinase (PK) [transformed and untransformed] and age in normal females from different racial subgroups

\begin{tabular}{lllllll}
\hline $\begin{array}{l}\text { Racial } \\
\text { group }\end{array}$ & $n$ & $\begin{array}{l}\text { Age } \\
x \pm s\end{array}$ & $\begin{array}{l}\mathrm{CK}(\mathrm{S} . \mathrm{u} . / \mathrm{ml}) \\
x \pm s\end{array}$ & $\begin{array}{l}\log (\mathrm{CK}+1) \\
x \pm s\end{array}$ & $\begin{array}{l}\mathrm{PK}(\mu \mathrm{mol} / \mathrm{ml} \text { per h) } \\
x \pm s\end{array}$ & $\begin{array}{l}\log (\mathrm{PK}+1) \\
x \pm s\end{array}$ \\
\hline $\begin{array}{l}\text { Caucasoids } \\
\begin{array}{l}\text { Negroids } \\
\text { a. Light }\end{array}\end{array}$ & 40 & $29.2 \pm 7.9$ & $3.65 \pm 2.65$ & $0.62 \pm 0.25$ & $2.54 \pm 0.74$ & $0.54 \pm 0.08$ \\
$\quad \begin{array}{l}\text { mulatto } \\
\text { b. Medium } \\
\quad \text { mulatto }\end{array}$ & 47 & $28.9 \pm 6.4$ & $4.19 \pm 1.79$ & $0.69 \pm 0.16$ & $2.25 \pm 0.69$ & $0.50 \pm 0.09$ \\
$\begin{array}{l}\text { c. Dark } \\
\quad \text { mulatto }\end{array}$ & 45 & $30.2 \pm 8.2$ & $5.97 \pm 2.88$ & $0.80 \pm 0.20$ & $2.27 \pm 0.60$ & $0.54 \pm 0.08$ \\
$\begin{array}{l}\text { d. Black } \\
\text { Mongoloids }\end{array}$ & 41 & $32.2 \pm 8.8$ & $6.79 \pm 5.74$ & $0.81 \pm 0.26$ & $2.33 \pm 0.72$ & $0.51 \pm 0.08$ \\
\hline
\end{tabular}

A significantly higher $\mathrm{CK}$ activity was observed in the negroid subgroups than in the caucasoid females $(t=3.9 ; P<0.001)$. Furthermore, the CK activity varied and increased significantly with the degree of black admixture $(F=5.08 ; P=0.001)$ but not with age $(F=1.59 ; P=0.21)$. The mean $\mathrm{CK}$ activity in caucasoid females was significantly lower than in the groups of medium mulattoes, dark mulattoes and black females $(P<0.05)$, but was not significantly different from light mulattocs $(P>0.05)$.

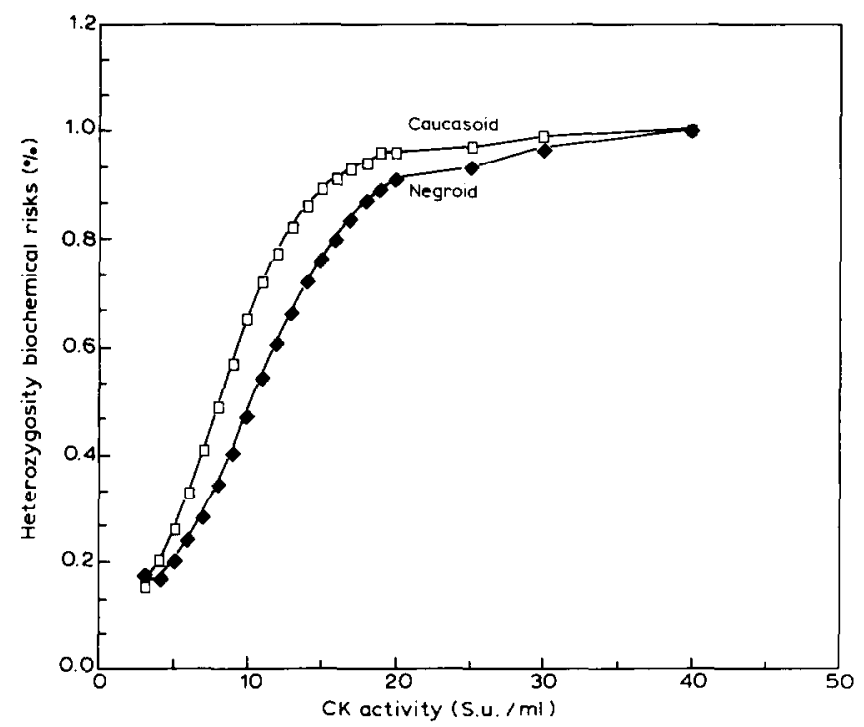

Fig. 1. Heterozygosity biochemical risks by serum creatine-kinase (CK) for carrier status according to ethnical background. 
The mean $\mathrm{CK}$ activity did not differ between mongoloids and caucasoids $(t=1.48 ; P>0.05)$; therefore, these two samples were joined for further analyses (group CM).

On the other hand, the PK levels did not show any statistically significant difference between caucasoids and negroids ( $F=1.02 ; P=0.41)$.

In order to evaluate the influence of black admixture on $\mathrm{CK}$ activity in the estimation of heterozygosity risks, conditional biochemical probabilities using a quadratic discriminant analysis [4] were determined considering the ethnical background from both carriers and controls. The estimated biochemical probabilities favoring the diagnosis of heterozygosity for caucasoid and negroid DMD carriers are shown in Fig. 1.

\section{Discussion}

\section{Effect of black admixture on serum $C K$ levels in healthy controls}

Results from the present investigation confirm previous studies suggesting that serum CK activity is higher in healthy negroid females than in caucasoids [7-10] and are similar between caucasoids and mongoloids [9].

However, the gradual increase in the mean CK activity according to the degree of black admixture was apparently not reported previously in females, but only in healthy males [8].

The higher CK activity found in negroids than caucasoids is still the subject of investigation. According to Meltzer [7] nutritional or physical activities differences are apparently not implicated in these results, and might be related to a greater muscle mass in the negroid group. More recently, Ama et al. [17] reported a higher muscle CK activity and a higher proportion of type $2 a$ fibers in negroid than caucasoid young sedentary males.

It is important to observe that the females ascertained in the present study belong to the same social condition with similar nutritional habits and physical activities. Since the racial classification reflects genetic differences among the different negroid subgroups [13], the results on CK activity seem to confirm the genetic influence on serum enzyme levels already suggested by some authors. Indeed, comparative studies on serum $\mathrm{CK}$ in normal twins showed a higher concordance in monozygotic than in dizygotic twin $[18,19]$.

The present results on PK activity confirm our previous suggestion that this enzyme is not influenced by race, as observed previously in a smaller sample of healthy controls [11].

Estimation of heterozygosity biochemical risks for females at risk for DMD according to racial background

Among serum enzymes, the creatine-kinase (CK) test is the most reliable and widely used. The concomitant use of serum PK may improve the capability of detecting heterozygotes females in about $10 \%[2,3]$.

Several factors have been reported to affect serum CK activity in DMD carriers such as age, pregnancy and physical exercise [5]. 
Recently Zatz et al [12] reported in females at risk for DMD the same effect which was found in healthy female controls, that is, a higher mean serum CK in negroids than in caucasoids but no significant difference in mean serum PK between these two populations. It was suggested that the CK difference was more likely due to the racial background rather than genetic heterogeneity in the DMD locus. This was supported also by a previous observation showing that the CK activity in caucasoid DMD boys did not differ from negroids [20].

Through DNA technology a great improvement in the identification of females at-risk for DMD has been achicved. However, to detect all femalcs at-risk for DMD-BMD gene using only DNA probes is still difficult due to the extremely large size of this locus and its reported molecular heterogeneity [6]. The recent identification of dystrophin, described as the protein product of the Duchenne muscular dystrophy gene [21], may represent in the next future, a great step forward the detection of DMD carriers. However, if the DMD gene is expressed mainly in muscle [22], it would require a muscle biopsy, which is not an easy routine procedure. Therefore, results of simple tests, such as serum CK determinations, will still be important as screening and also as an adjunct for estimation of conditional probabilities.

The discriminant functions derived from serum enzyme activity show that the conditional biochemical probabilities favoring the diagnoses of heterozygosity for DMD varied for some CK values between caucasoids and negroids (Fig. 1). For example, if we consider a CK value of $11.0 \mathrm{~S} . \mathrm{u} . / \mathrm{ml}$, the biochemical probability for a female at-risk being a DMD carrier is $72 \%$ if she is a caucasoid and $54 \%$ is a negroid. These probabilities, combined with data from pedigree through Bayesian calculations will give a final estimate of heterozygosity risks for suspected carriers.

Therefore, based on the above observations it is suggested to take into account racial background for estimation of heterozygosity risks. Such considerations are not necessary for PK as its activity does not seem to vary according to the ethnical background in controls or DMD carriers.

\section{Acknowledgements}

The authors thank Dr. José Antonio Levy and Paulo Salum for refering patients and DMD families; Mrs. Marta Canovas and Mrs. Direynia B. Costa for technical assistance; to Dr. Paulo A. Otto and Dr. Fernando Carvalho for statistical analysis; to Dr. David Campion for support; to Debora Rapaport and Mariz Vainzof for reviewing the manuscript. This work was supported with grants from FAPESP, CNPq, CAPES and MDA from America.

\section{References}

1 Zatz M, Frota-Pessoa O, Levy JA, Peres CA. Creatine-phosphokinase (CPK) activity in relatives of patients with X-linked muscular dystrophies: A Rrazilian study. I Genet Hum 1976;24:153-168.

2 Percy ME, Chang IS, Murphy EG, Oss I, Verellen-Dumoulin C, Thompson MW. Serum creatine-kinase and pyruvate-kinase in Duchenne muscular dystrophy carrier detection. Muscle nerve 1979;2:329-339. 
3 Zatz M, Shapirto LJ, Campion DS, Kaback MM, Otto PA. Serum pyruvate-kinase (PK) and creatine-phophokinase (CPK) in females relatives and patients with $\mathrm{X}$-linked muscular dystrophies (Duchenne and Becker). J Neurol Sci 1980;46:267-279.

4 Zatz M. Otto PA. Evaluation of carrier detection rates for Duchenne and Becker muscular dystrophies using serum creatinekinase $(\mathrm{CK})$ and pyruvate-kinase (PK) through discrimination analysis. Am J Med Genet 1986;25:219-230.

5 Gruemer H.-D., Prior T. Carrier detection in Duchenne muscular dystrophy: a review of current issues and approaches. Clin Chim Acta 1987;162:1-18.

6 Lindlof M, Sistonen P, De La Chapelle A. Linked polymorphic DNA markers in the prediction of X-linked muscular dystrophy. Am Hum Genet 1987;51:317-328.

7 Meltzer HY. Factors affecting serum creatine phosphokinase levels in the general population: the role of race, activity and age. Clin Chim Acta 1971;33:165-172.

8 Meltzer HY, Holy PA. Black-white differences in creatine-phophokinase (CPK) activity. Clin Chim Acta 1974;54:215-224.

9 Wong DS, Cobb C, Umehara MK, et al. Heterogeneity of serum creatine kinase activity among racial and gender groups of the population. Am J Clin Pathol 1983;582--586.

10 Black HR, Quallich H, Gareleck CB. Racial differences in serum creatine kinase levels. Am J Med 1986;61:479-492.

11 Passos MR, Azevedo ES, Zatz M. Creatine-kinase (CK) and pyruvate-kinase (PK) levels in normal females of different racial groups in Brazil: Implications for the detection of Duchenne muscular dystrophy (DMD) carriers. Muscle nerve 1986;9(55):262.

12 Zatz M, Passos MR, Rabbi-Bortolini E, Vainzof M, Rapaport D, Rocha JML, Pavanello RC. Serum creatine and Pyruvate-kinase (PK) levels in females at-risk for Duchenne muscular dystrophy (DMD) from different racial background. Rev Bras Genet 1988; in press.

13 Azevedo ES. Subgroup studied of black admixture within a mixed population of Bahia, Brazil. Ann Hum Genet 1980;44:55-60.

14 Zatz M, Shapiro LJ, Campion DS, Oda E, Kaback MM. Serum pyruvate-kinase and creatine-phosphokinase in progressive muscular dystrophies. J Neurol Sci 1976;36:349-362.

15 Hughes BP. A method for the estimation of serum creatine kinase and its use in comparing creatine kinase and aldolase activity in normal and pathological sera. Clin Chim Acta 1962;7:597-603.

16 Sigma Technical Bulletin. Creatine phosphokinase (CPK) in serum or plasma. Sigma Chemical Co. (Publ.), St. Louis, MO, 1985; No. 520.

17 Ama PFM, Simoneau $J \wedge$, Boulay MR, Serrense O, Thériault G, Bouchard V.C. Skelctal musclc characteristic in sedentary black and caucasian males. Am Phys Soc 1986;61:1758-1761.

18 Meltzer HY, Belmaker RJ, Wyatt W, Pollin W, Cohen S. Serum creatine phosphokinase (CPK) activity in monozygotic twins discordant for schizophrenia: heritability of serum C.PK activity. Comp Psychiat 1976;17:469-475.

19 Rapaport D, Colletto GMDD, Zatz M. Genetic and environmental components of serum creatinekinase (CK) and pyruvate-kinase (PK) in normal twins: implication for genetic risks estimates in Duchenne dystrophy carriers. Am J Med Genet 1988 ; in press.

20 Rabbi-Bortolini E, Zatz. M. Duchenne muscular dystrophy: comparison among different racial groups. Am J Med Genet 1987;28:925-929.

21 Hoffman EP, Brown Jr RH, Kunkel LM. Dystrophin: The protein product of the Duchenne muscular dystrophy locus. Cell 1987;51:919-928.

22 Hoffman EP, Hudecker MS, Rosenberg PA, Pollina CM, Kunkel LM. Cell and fiber-typer distribution of dystrophin. Neuron 1988;1:411-420. 